\title{
Service Delivery and Performance of Kenya Commercial Bank Limited: A
}

\section{Critical Review of Literature}

\author{
Francis Chesaina ${ }^{l}$, Esther Gitonga ${ }^{1}$ \\ School of Business, Kenyatta Universityl
}

\section{ABSTRACT}

The overall goal of any business entity is to have the needs of customers satisfied. In the business world customers are the source of profit and revenue for the service organizations and improvements in service delivery leads to customer loyalty. Rapid developments in the business environment such as globalization have made organizations to adopt a spirit of completion and innovation so as to be able to meet the equally changing customer needs and expectations. In order to compete effectively, it has become essential for businesses to constantly improve on the quality of their products and services by marketing, product differentiation and cost reduction. The changes in the environment is forcing organizations to move from a retail model that emphasizes transaction processing and operational capabilities to one that focuses more effectively on the needs of customers, recognizing that they often vary across segments. In a move to optimize services and diminish costs, banks are regularly migrating towards a twenty four hour service where clients are enjoying the superior sense of independence that this creates. This study seeks to establish the effect of service delivery on performance of Kenya Commercial Bank Limited, Kenya. The review is based on SERVQUAL model Systems, Modelling Theory, Gaps Model of Service Quality and Theory of Performance. The literature reviewed indicates that service delivery by Kenya Commercial Bank improves organization performance. However, the specific service delivery channels and tools are noted to differ from one organization to the next. The level of service delivery will also be different and expected to influence organization performance. This is in line with SERVQUAL that requires assessing level and type of service delivery would lead to higher customer satisfaction and thus organization performance. The level of service quality in term of reliability, assurance, tangibles, empathy and responsiveness are crucial to be studied. This review therefore recommends for an empirical study to assess how service delivery affects performance at KCB. KCB management is also recommended to put in place mechanisms of ensuring sustained service delivery and thus maintain above competition organization performance.

Key Words: Service Delivery, Organization Performance, Commercial Banks in Kenya, Kenya Commercial Bank Limited

DOI: 10.7176/ijcab.v3iII.7, URN: urn:nbn:de:0000ijcab.v3iII.73

\section{INTRODUCTION}

The dynamic and focused condition requests conveying top notch service for a supportable upper hand (Angelova \& Zekiri, 2011). Quick advancements in the business condition, for example, globalization have made associations to embrace a soul of finish and development in order to have the capacity to meet the similarly changing client needs and desires. So as to contend successfully, it has turned out to be basic for organizations to continually enhance the nature of their items and services by showcasing, item separation and cost decrease. The adjustments in the earth is compelling associations to move from a retail show that stresses exchange preparing 
and operational capacities to one that centers all the more viably around the necessities of clients, perceiving that they frequently shift crosswise over fragments. In a move to advance services and lessen costs, banks are routinely relocating towards a twenty four hour service where customers are getting a charge out of the prevalent feeling of freedom this makes (Awinja, 2015). To empower associations contend viably, it is important that they always upgrade nature of their items and services through different practices, for example, separation of items and services and raising execution through decrease of expenses. This examination has attempted to explore the service delivery in KCB in light of the fact that as indicated by Business today (2018) Cytonn Investments Kenya Commercial Bank (KCB) has been positioned as the most appealing bank in Kenya, a position it has held since 2015. This is upheld by a solid establishment esteem and furthermore inborn esteem score. The establishment esteem estimates the expansive and extensive business quality of a bank crosswise over 13 unique measurements while inborn score estimates the speculation return potential. The KCB Group was positioned first position on the back of an exceptional yield by and large value of $20.3 \%$ contrasted with an industry normal of $18.4 \%$, just as an ideal advance to store proportion of $84.3 \%$, contrasted with an industry normal of $76.8 \%$. This in spite of the horde of client objections rising on the dimension of service delivery in $\mathrm{KCB}$ being one of the banks that the administration of Kenya has genuine shareholding.

There has been a colossal change in the method for banking and clients have likewise appropriately requested world class quality services from the banks. With numerous decisions accessible, clients are not willing to endure anything short of the best service delivery. Banks have perceived the need to meet clients' yearnings as various clients have distinctive identities, so it is a pressing drive for the banks to build up the determinants of client dependability in the banking part so as to improve client reliability and maintenance. Banking establishments have figured out how to exhibit commendable execution and furthermore improved their outcomes paying little heed to firm challenge for a bit of the market. The commercial banks figured out how to stay truly steady, the stores and resources of investors expanded by $35.35 \%$ and $32.9 \%$ individually (Central Bank of Kenya, 2015). There are various administration styles connected in associations so as to accomplish objectives, set destinations and focuses of their business. The investigation in surveying service delivery in $\mathrm{KCB}$ has examining factors, for example, unmistakable innovation, unwavering quality, responsiveness and compassion. These are on the whole parts of service delivery and are impacting everything to decide the achievement or disappointment of service delivery in Kenya Commercial Bank Limited.

As per Agus, Barker and Kandampully, (2007), service delivery is essential and affects consumer loyalty, improving deals and piece of the overall industry. The service conveyed as expressed by Parasuraman, Zeithaml and Berry (1994) incorporate effects that is the physical proof of the service: appearance of physical offices, instruments and gear used to give the service, appearance of work force and correspondence materials, furthermore is unwavering quality which is the capacity to play out the guaranteed service reliably and precisely: consistency of performance and reliability, service is performed directly at the first run through, the organization stays faithful to its obligations in exactness in charging and keeping records accurately, playing out the services at the assigned time, third is the responsiveness that is the eagerness or availability of representatives to support clients and to give brief service, auspiciousness of service: mailing an exchange slip promptly, setting up arrangements rapidly, fourth is affirmation which is the information and affability of representatives and their capacity to pass on trust and certainty: ability that is ownership of the required aptitudes and learning to play out the service. Service 
delivery includes a correlation of desires with performance. The training requests quality in all elements of the organization's endeavors with things done as wanted from the beginning and any wastage and deteriorations being kept to the base amid routine business (Stock and Mulki, 2009).

Globally organizations have grasped the idea of service delivery as a procedure with many fusing the idea into their statements of purpose (Salim, 2016). For instance, Valero Energy Corporation is focused on guaranteeing a positive retail experience for clients by concentrating on comfort, esteem and quality. Dell PCs center around conveying the best client involvement in the business sectors the firm serves, while Toyota's statement of purpose is to continue gainful development by giving the best client experience and seller support. An IBM report likewise distinguishes client service as a key factor in their technique for organizations to use in structure dependability to brands, channels and services (Salim, 2016). In Africa, it is seen that the bank client recently is progressively educated, requesting, scientific and mindful of his/her rights and accordingly might not want to be dealt with at any rate or given unacceptable service (Asante and Kwasi, 2012). In Ghana; the extraordinary challenge in the previous years because of new participants into the business both nearby and outside and authorization of Bank of Ghana guidelines has requested the need to offer high service quality to separate contributions in the commercial center. This is in an offered to pull in and hold clients and increment client certainty (Amoako, 2012). As indicated by (Moller, 2008) clients of retail banks in Africa are plainly looking for a responsive service, with an abnormal state of staff effectiveness. This would recommend that endeavors to build speed of handling data and clients are probably going to have a critical and constructive outcome on consumer loyalty. Tending to this issue through normal staff preparing ought to improve service quality. Shorter lines, service unwavering quality and advantageous areas are additionally viewed as critical by clients. For retail banks in Africa needing to upgrade consumer loyalty, these future key regions for development.

In Kenya, the dimension of rivalry and high client desires is fiercer in the service business. Kenya's service industry is the biggest supporter of its total national output represents around 63 percent of its GDP (World Bank, 2008). The banking part in Kenya is controlled and directed by the Central Bank of Kenya. The division has become massively throughout the years; it as of now has 43 authorized commercial banks and 1 contract account organization. Out of the 44 money related organizations, 31 are privately claimed while 13 are outside possessed. The privately possessed money related foundations contain 3 banks with huge shareholding by the Government and State Corporations, 27 commercial and 1 contract fund establishment. By 2012 the part had 8 store taking microfinance organizations, 7 agent workplaces of remote banks, 108 outside trade authorities and 2 credit reference departments (Central Bank of Kenya, 2015). Customary methods for banking through physical branch organize have advanced to interchange channels to incorporate charge and Visas, web banking and cell phone exchanges. The banking division in Kenya is feeling the squeeze to improve their nature of service delivery, while likewise decreasing expenses to stay focused in a very unstable and questionable market. Improving client service is basic for banks in the present market and financial situation, where item and value never again give a reasonable aggressive edge (CBK, 2014). Service delivery channels assume a key job in conveying an upgraded client experience as client connections start and end with channels. Banking clients are progressively anticipating more accommodation, openness, personalization and unwavering quality crosswise over dispersion channels organize. There is an unmistakable interest for banks to put resources into their channel organizes as a system to make them more clients' driven and easy to use, while in the process improving the 
channel efficiencies for better profit for ventures, operational performance and expanded productivity (Valluri, 2012).

Kenya Commercial Bank Limited began in Kenya in July 1896 when its forerunner, the National Bank of India opened an outlet in Mombasa. Later the Bank stretched out its activities to Nairobi, which had turned into the Headquarters of the growing railroad line to Uganda. In 1958, Grindlays Bank converged with the National Bank of India to shape the National and Grindlays Bank. Upon freedom, the Government of Kenya obtained 60\% shareholding in National and Grindlays Bank with an end goal to convey banking nearer to most of Kenyans. In 1970, the Government assumed full responsibility for the Bank and renamed it to Kenya Commercial Bank Group. The Kenya Commercial Bank in 1972 gained Savings and Loan (K) Ltd to have practical experience in home loan account and in 2010 Savings and Loans converged with Kenya Commercial Bank to give access to contract money through the bank's wide branch organize.

\section{THEORETICAL REVIEW}

This section reviews the theories propounded by various scholars which are used to explain service delivery. These theories include SERVQUAL model and gaps model theory.

\subsection{SERVQUAL (Service Quality) Model}

This model structures the premise of this investigation. Parasuraman, Zeithaml, and Berry (1985) created service quality model which is named as SERVQUAL model or PZB show. They had directed center gathering meeting so as to build up the principal variant of SERVQUAL demonstrate. They had made ten elements of the service delivery by deciding the comparative criteria in the assessment of client. The ten elements of service quality included substantial quality, dependability, responsiveness, fitness, get to, obligingness, correspondence, validity, security and comprehension. SERVQUAL is a multi-thing scale created to evaluate client impression of service quality in service delivery and retail organizations (Parasuraman et. al., 1994). The hypothesis of service quality has five measurements, effects, dependability, responsiveness, sympathy and affirmation. SERVQUAL speaks to service quality as the error between a client's desires for a service offering and the client's view of the service got, expecting respondents to address inquiries concerning both their desires and their recognitions (Parasuraman et. al., 1994). The utilization of saw instead of real service got makes the SERVQUAL measure a disposition measure that is identified with, however not equivalent to, fulfillment (Parasuraman et. al., 1994). Parasuraman et al. (1994) displayed a few corrections to the first SERVQUAL measure to cure issues with high methods and standard deviations found on certain inquiries and to acquire an immediate proportion of the significance of each build to the client.

SERVQUAL is based on the hope disconfirmation worldview, which in straightforward terms implies that service quality is comprehended as the degree to which customers' pre-utilization desires for quality are affirmed or disconfirmed by their genuine impression of the service involvement. The analytic estimation of the instrument is upheld by the model of service quality which shapes the theoretical system for the advancement of the scale (for example instrument or survey). The instrument has been broadly connected in an assortment of settings and social settings and observed to be generally hearty. It has turned into the prevailing estimation scale in the territory of service quality. Regardless of the long-standing enthusiasm for SERVQUAL and its horde of setting explicit applications, it has pulled in some analysis from scientists. Service quality and consumer loyalty are vital ideas that organizations must comprehend so as to stay 
aggressive in business and henceforth develop. It is essential for organizations to realize how to gauge these develops from the shoppers' point of view so as to more readily comprehend their necessities and consequently fulfill them. Service quality is viewed as essential since it prompts higher consumer loyalty, benefit, decreased cost, client devotion and maintenance. This model is relevant to this study since it will be used to assess level and type of service delivery would lead to higher customer satisfaction. Higher customer guarantees repeat purchases and increased customer base. Service quality includes the elements of RATER model: reliability, assurance, tangibles, empathy and responsiveness, (Seyed, 2015). The model is also relevant for it will be used in the commercial banks as a strategy to ensure continuity of business and higher returns.

\subsection{The Gaps Model of Service delivery}

The SERVQUAL approach recognizes five holes that present a difference among desires and view of real service delivery (Palmer, 2014). Zeithmal et al (1993) recognized the initial four potential holes inside the service association that may prompt a fifth and most genuine hole - the contrast between what the clients expected and what they saw was conveyed. The principal service holes recognized is the information hole which clarifies the distinction between what senior administration trusts clients expect and clients' real needs and desires. The board may fail in accepting they realize what clients expect, and may even continue to convey dependent on this incorrect presumption, which contrasts from the client desire. The second service hole is the approach hole. The approach hole is the distinction between what the board comprehends of clients' desires and the quality guidelines built up for service delivery. On the off chance that administration neglects to set clear quality or unattainable quality details, at that point they can make an arrangement hole. Setting service principles underneath client desires additionally presents a strategy hole. This occasionally happens when the executives is driven by expense or possibility contemplations amid testing monetary occasions. The third hole is the delivery hole. The delivery hole is the contrast between determined service delivery measures and the delivery group's and service tasks' real performance on these guidelines. Zeithmal et al (1993) clarify that unanticipated issues or poor administration can prompt a service supplier neglecting to meet service quality particulars either because of human blunder or because of mechanical breakdown of encouraging or bolster great. The fourth hole concurring is the correspondence hole which clarifies the distinction between what the organization imparts and what it really conveys to its clients. This hole is brought about by two sub-holes.

First is the inner interchanges hole which is the contrast between what the organization's promoting and deals group believe are the items highlights, performance, and service quality dimension and that the organization is really ready to convey. Second is the overpromise hole that can be brought about by publicizing and deals group promising clients past what the association is fit for conveying. Ordinarily forceful deals evaluations concentrated on deals volumes can lead the business groups to overpromise and henceforth baffle clients. The fifth hole is the discernments hole which is the distinction between what is, truth be told, conveyed to the client and what clients see they have gotten (on the grounds that they are now and again unfit to precisely assess service quality). The 6th hole is the service quality hole that clarifies the contrast between what clients hope to get and their impression of the service that is really conveyed. At the point when this hole is encountered, the client impression of real service delivery varies from their underlying desire. Zeithmal et al (1993) contended that the quality of the service holes display was that it offers conventional experiences and arrangements that can be connected crosswise over businesses. These arrangements goad associations to devise measures to close 
explicit holes existing in the organizations. Each firm needs to devise components that there satisfactory spotlight on service quality as a key goal.

\section{EMPIRICAL REVIEW}

This reviews empirical evidence from various studies on technology tangibles, continual improvement, service reliability and service responsiveness on performance of commercial banks in Kenya. Remarkable changes have come about due to the innovation that has happened in the information technology. This has brought about changes in the demands patterns in the society. With these effects, there is an increasing need to involve technology in passing on skills in the 21st century, because its adoption has reformed health, education and other key systems. Additionally, these changes have brought about the adoption of new methods of production hence educating people new skills on various areas so as to raise productivity (Tomei, 2005). All commercial banks supply some type of service internally and externally. Tangible technology which commercial banks focus on includes aspects like ATMs, ATM Cards, and electronic money transfers. Pelgrum and Law (2003) expressed that close to the finish of the 1980s, the term 'PCs' was supplanted by 'IT' (data innovation) implying a move of center from figuring innovation to the ability to store and recover data. This came about because of the acquaintance of data correspondence innovation with the overall population in the mid 1990s. ICT incorporates arrangement of web services, IT hardware and media communications devices.

Innovation as an empowering agent of the delivery of prevalent banking services is all around recorded in the promoting writing. Abora (2011) noticed that banks have moved rapidly to put resources into innovation as a method for controlling costs, pulling in clients and meeting the comfort and specialized desires for their current clients. Joseph and Stone (2003) additionally note that the portion of client cordial innovation, (for example, menu-driven computerized teller machines, phone and web banking services has turned out to be ordinary lately as a method for keeping up client steadfastness and expanding piece of the overall industry. They likewise note that when a client openly utilizes innovation as a type of service delivery, the effect on that client is high as far as the association's quality properties like proficiency and speed (Abora, 2011). Joseph and Stone (2003), contend that as long as the trade starting with one of delivery service then onto the next does not antagonistically affect the relationship building capacity played by bank representatives, or result in critical weakening in the nature of service conveyed then innovation ought to be progressively embraced particularly in offering clients self-service choices. Curry and Penman (2004) contend that mechanical advancement in the United Kingdom has prompted the depersonalization of the service delivery process and the "human factor" between the banker and client at the neighborhood level . They anyway concede that improved service arrangement, with the correct blend of human info and innovation will hold clients in the long haul. This position upheld by Curry and Penman (2004) encapsulates the service quality conceptualized for this examination as an attention on client service, bank learning and bank innovation.

Unwavering quality demonstrates the service supplier's capacity to perform services in a reliable and exact way. Unwavering quality includes doing it right the first run through and it is a significant service segment of clients (Odhiambo, 2015). Dependability improvement is the key factor in service quality upgrade endeavors. This is on the grounds that when a firm is questionable, conveys less worry to what clients care about. Clients may shape a negative recognition about the firm and will change to a contender without even batting an eye. Clients view, involvement and judge accidents in the service delivery promptly they communicate when 
services are being advertised. It is troublesome for service suppliers to control such varieties since every worker is to some degree not quite the same as the others in identity, aptitudes and demeanors. The key viewpoints under unwavering quality incorporate giving service as guaranteed, steadfastness in dealing with client service issues, performing services directly at the first run through and keeping up blunder free records (Odhiambo, 2015). As indicated by Klemz and Boshoff (2011), the significant purpose behind clients to pick banks for speculation reserves is a direct result of the unwavering quality and notoriety of banks. Banks as a rule give their oath to clients about security amid exchanges. Ramzi (2010) called attention to that giving services as guaranteed is one of the imperative variables of consumer loyalty. A decent method for inspiring clients is by doing what you guaranteed and doing it directly at the first run through involvement. This will improve rehash business. Research has demonstrated that delivery is the most critical factor for clients and is one of the fundamental driver of record surrender if not accomplished (Messay, 2012). Giving service as guaranteed is subsequently key in any business as this will assemble an organizations' notoriety and with great notoriety, there is high odds of rehash business. What's more, new business will be created by overhearing people's conversations and it will separate a bank from its rivals also. As indicated by Lau, Cheung, Lam and Chu (2013) giving services as guaranteed is additionally critical at the bank in such a case that a client is anticipating that the bank should accomplish something for them, they ought to have the capacity to depend on them to do it on the day that they need it done. A noteworthy issue looked by purchasers in the banking business is the timings assigned for services offered (Lau et al., 2013). Typically, most banks working days in Kenya are from Monday to Friday and they work from $8.30 \mathrm{am}$ to $4.30 \mathrm{pm}$, however because of shopper request, the pattern changed, with the banks starting services an hour sooner and some work on ends of the week. Other than the banking hours, lining up at certain banks while the banks guaranteed snappier services ends up irritating to customers (Ouyung, 2010).

Despite the fact that most banks have presented seats, no purchaser needs to hold up longer than required in a banking lobby. In that capacity, most banks currently have built up an approach to address customer issues. A precedent is a recommendation box put at the passageway of the bank. Rehash deals are not inadvertent, they happen because of a relationship that is made when a firm offers service as they had guaranteed. Building relationship in business is along these lines of incredible significance Karim and Chowdhury (2014) contended that banks are contending all around to hold current records, and to sign on new ones to demonstrate that they are reliable. In the present economy, we never again have an industry in which great promotions and corporate social duty will acquire clients. A firm needs to demonstrate to clients why they should remain faithful to them and not change to a contender definitely. Bank clients every now and again take a gander at any signs that might be utilized as pointers of steadfastness as these will empower them to pass judgment on the services delivery of the banks and the bank's workers (Odhiambo, 2015). Giving service in an opportune way is exceptionally valued by clients. Firms that esteem proficiency focus on the services that they offer so they can have preference and utilize this to keep off contenders (Karim, 2014). Clients search for banks that eagerly help them in their banking activities. Key angles under responsiveness incorporate keeping clients educated with respect to when services will be performed; brief service to clients, ability to support clients and preparation to react to clients demand (Odhiambo, 2015). As indicated by Timothy (2012) the means taken to keep clients educated when issues happen can reinforce or hurt the relationship. Keeping clients all around educated of what is happening can effectsly affect the relationship. By giving clients a chance to work out their issues and not being proactive, firms pass up on a chance to reinforce client connections. Other than being prepared on the most proficient method 
to manage clients, representatives ought to be given the opportunity to empower them use watchfulness in educating clients on the advancement of their interest and a stage of asking when they don't know (Saghier and Nathan, 2013). Representatives should know their clients' needs and what they think about the firm. Firms might probably create associations with clients that will profit the two gatherings by conversing with them about their requirements. I

Standard and legit input while educating clients is an absolute necessity. For this to happen appropriately, firm staff must be proactive and explicit. The firm ought to have the capacity to build up an advancement and improvement plan. In addition it ought to have the capacity to connect the representative's performance with the organizations' objectives so they can offer services that will fulfill clients. Brief service to clients incorporates giving convenient reactions to client questions and request, and educating your customers expeditiously. Welcome them heartily, including them to figure out what they have sought, and reacting immediately and precisely to request demonstrate clients' fast comprehension of the firm and the client will see the service supplier as being sufficiently skilled to offer the service. The client won't be fulfilled on the off chance that the person feels that the services offered generally deferral and it achieves question the ability of the service supplier (Ramzi, 2010). The service that the representatives give and the connections they construct are imperative to achievement of consumer loyalty. Unfavorable reaction to client demand is one of the stamps of poor client service and the client feel not esteemed. They need to know their essence and contribution to the business is valued. Initial introduction greatly affects clients thus how firms react to and treat clients out of the blue decides if they will return. In the event that very much served they may prescribe the bank to other people (Messay, 2012). In the enrollment condition, a firm needs to contend with comparable firms to get the best individuals with this sort of demeanor. Exhibiting that you are tuning in through non-verbal communication and looking demonstrates a client that you are eager to help them. Frame of mind will dependably have an advantage contrasted with inclination. Most firms will pick representatives willing to go the additional mile or show penance over some with more noteworthy specialized abilities while procuring. Usually simple to expand the specialized abilities than change hesitant conduct a representative without the common want to serve and eagerness when managing clients. This is on the grounds that their free soul nature to help the client causes them in holding and drawing in new clients to the bank (Ouyung, 2010).

The premise of compassion is established in understanding the requirements of clients and giving them singular consideration. Representative and client communications are reflected through the sympathy measurement (Armstrong, 2012). Clients have a desire on how the service supplier ought to comprehend and be worried about their individual needs and needs (Toosi and Kohonali, 2011). Appearing understanding and having information to take care of clients' issues are key factors in the banking business. The key angles under compassion incorporate giving clients' individual consideration in a minding style by workers who comprehend their requirements (Armstrong, 2012). Clients welcome an organization that offers them choices and choices, particularly when the organization agents make them feel like they would lke their clients to have the best advantages by giving them singular consideration (Kariru and Aloo, 2014). It is imperative not exclusively to comprehend what a client says, yet how a client feels to give them the ideal consideration. An expected expertise to help with offering this is having the capacity to perceive and comprehend client's passionate state. Lau et al. (2013) called attention to that organizations with great service notoriety welcome and acknowledge negative criticism from the individual clients. In spite of the fact that they won't make changes dependent on all 
proposals, they realize that it is just by hearing straightforwardly from the client and focusing. From the input they can recognize what is absent in their service delivery that push individuals away (Timothy, 2012). Each connection with a client is an opportunity to focus and realize what's vital to that person. From that advantage point, banks may alter the result to make it extraordinary to that client. At the point when done more than once, it might appear to be typical to the service supplier however it ought to be done such that it feels individual and one of a kind to the client each time they are being served (Akbar and Parvez, 2009).

Gbadeyan and Gbonda (2011) called attention to that workers are the cutting edge of a business, speaking with the clients and speaking to the firm on an everyday premise. Clients whenever abused or disregarded by the representatives, they don't generally grumble about what they feel as unoriginal service. Rather, they will stay away for the indefinite future and this is something that unquestionably no business needs (Klemz and Boshoff, 2011). A business that utilizes individuals who like what they do draws in clients and gives them a positive impression. Clients would need to work together when they get authentic and minding service from the organization's delegates (Angelova, 2011). To have representatives that truly esteem clients, there must be trust worked among them and the firm. The firm needs to think about what's critical with its representatives (Akbar and Parvez, 2009). Comprehending what is normal and requested from client service faculty from clients' perspective uncover unnoticed data. Workers who are agreeable and minding not just told clients that their solace is a need, yet in addition that the firm is productive and that they can confide in them with their business (Odhiambo, 2014). Jayanthy and Umaran (2012) proposed that knowing and understanding client needs is at the core of each fruitful business, regardless of whether it offers straightforwardly to people or different organizations. Each business needs an explanation behind their clients to purchase from them and not their rival. Organizations like Argos and Cadburys have remarkable dimensions of consumer loyalty. It isn't amazing in light of the fact that these organizations accentuate statistical surveying and showcasing as the instruments for discovering what clients need and need. Recognizing what clients need and making it conceivable to guide activities to satisfy their requirements will bring devotion. As indicated by Kariru and Aloo (2014), representatives in firms ought to have adaptable, peaceful work environments that will empower them manage clients to give services in a practical manner and without hurting the firm notoriety or pursuing ceaselessly the client. The similarity of the materials utilized for the service will improve by and large representative profitability and mission performance. Banks' dedication of understanding the necessities of their client is essential, as clients may spare a huge aggregate of cash in banks. For confused items, for example, protection, assets, and edges, representatives should truly comprehend its customers' needs and give a reasonable clarification of every item to clients. At the point when clients are offered the services that they need, they will have a feeling of having a place that can result in them being faithful to a specific firm.

\section{SUMMARY}

In Bangladesh, Karim and Chowdhury (2014) carried a research on customer satisfaction and agreed that service delivery is a critical business requirement. The study also established that the combination of tangibility, reliability, responsiveness, assurance and empathy together have significant effect on quality of service delivery on customer satisfaction. In Nigeria, Goyit (2015) carried out a research study on service quality and financial performance of selected banks. The study evaluated the relationship between investments in service quality programmes and bank earnings, deposits and profitability and found out that there exists a correlation between bank's service quality attributes and repeat purchase decisions by bank customers. In Kenya, Wachira 
(2013) conducted a study on the effect of technological innovation on the financial performance of commercial banks in Kenya and found that customer assisted technology and customer independent technology were influencing performance, Guyo (2014) viewed four independent variables; ATM cards, debit and credit cards, internet banking and mobile banking and concluded that technology adoption positively influences performance of commercial banks in Kenya. Awinja (2015) carried a research on service delivery channels and operations performance concluded that ATMs increase accessibility of the bank services to the customers and that use of ATMs helps the bank attain efficiency in delivering customer services to a very great extent that respectively enhances performance through; getting competitive advantage plus reduced costs and increased profit margins. Odeny (2016) carried a study on the influence of service quality on performance of Barclays bank of Kenya limited and drew a conclusion that service quality has a significant influence and plays an important role in the business performance of Barclays Bank. According to Wafubwa (2013) efficiency is a key factor that may enhance performance of commercial banks in Kenya. Others factors cited included clientele influences, competition influences, source of funds, and leadership influence and promotional strategies. This study however considers how quality service delivery strategies influences performance of commercial banks in Kenya.

\section{CONCLUSION}

Banks play different roles in the financial systems and in the wider society. Supported by the latest technology, Banks are working to identify new business niches, to develop customized services, to implement innovative strategies and to capture new market opportunities (Munyoki, 2010). In recent years the banking industry in Kenya has seen high levels of competition from new entrants and has made Banks realize that the retail customer is their source of profitability. Various research studies have been conducted in the area of service delivery, customer satisfaction and competitiveness as well as behavioral intentions, (Parasuraman et.al 1994; Sanchez et.al 2007). In spite all the achievements in the banking industry the number of complaints from customers in the KCB cannot go unnoticed. Few studies have examined the different perceptions of customers on the delivery of services by Kenya Commercial Bank Limited. This is a significant gap and in order to identify the banks' strengths and or weaknesses, customer perceptions of service delivery is a basic instrument. The level of service delivery allows the $\mathrm{KCB}$ to differentiate itself from competitors by increased market share, providing opportunities for cross selling, improving customer relations and thus enhancing the corporate image. The literature reviewed indicates that service delivery by Kenya Commercial Bank improves organization performance. However, the specific service delivery channels and tools are noted to differ from one organization to the next. The level of service delivery will also be different and expected to influence organization performance. This is in line with SERVQUAL that requires assessing level and type of service delivery would lead to higher customer satisfaction and thus organization performance. The level of service quality in term of reliability, assurance, tangibles, empathy and responsiveness are crucial to be studied.

\section{RECOMMENDATION}

Service delivery plays vital role in improving organization performance. However service delivery is a function of various intertwined factors that must be considered by Kenya Commercial Bank in ensuring positive performance impact is achieved by service delivery. Literature is not conclusive on the nature of the relationship between service delivery and performance and the components of each. This review therefore recommends for an empirical 
study to assess how service delivery affects performance at KCB. KCB management is also recommended to put in place mechanisms of ensuring sustained service delivery and thus maintain above competition organization performance.

\section{REFERENCES}

Abora D. (2011) the impact of quality customer service on the performance of some selected Banks in Kumasi Metropolis

Agus, A., Barker, S., and Kandampully, J. (2007) an exploratory study of service quality in Malysian Public Service Sector, International Journal of Quality \& Reliability Management,

Akbar, M. M. \& Parvez, N. (2009) Effect of Service Quality, Trust and Customer Satisfaction on Customer Loyalty. ABAC Journal, 29(1), 24-38.

Angelova, B., \& Zekiri, J.(2011) measuring Customer Satisfaction with Service Quality Using American Customer Satisfaction Model (ACSI Model). International Journal of Academic Research in Business and Social Sciences, 1 (3), 232-258

Armstrong, K. (2012) Principles of Marketing, 14th Edition, New Jersey: USA Pearson Education Inc.

Awinja P (2015) Service delivery channels and operations performance of Commercial Banks in Kenya (Unpublished MBA Project), University of Nairobi

Curry, A. and Penman, S.(2004) the relative importance of technology in enhancing customer relationships in- a Scottish perspective", Managing Service Quality, Vol. 14 No. 4, pp.331-341.

Cytonn Investments, (2017) Transitioning to a more Disciplined and Efficient Sector

Gbadeyan, R. \& Gbonda, O (2011) customers' Preference For E-Banking Services: A Case study of Selected Banks in Sierra Leone, Australian Journal of Business and Management Research, 4,108-116.

Goyit M.G (2015). Service quality and financial performance of selected Hotels in Kano Nigeria, The Nigerian Journal Of management Research

Guyo J.A. (2014). Effect of technology adoption on operational efficiency of commercial in Nigeria. A thesis in the department of business administration, faculty of management sciences submitted to the school of postgraduate studies, university of JOS,

Jayanthy, M. \& Umarani, R. (2012)Customers'Perception and Satisfaction towards Internet Banking Services. International Journal of Multidisciplinary Research 2(8), 63-71.

Joseph, M. and Stone, G. (2003) an empirical evaluation of US bank customer perceptions of the impact of technology on service delivery in the banking sector", International Journal of Retail \& Distribution Management, Vol. 31, No. 4, pp. 190-202.

Karim, A. \& Chowdhury, T. (2014).Customer Satisfaction on Service Quality in Private Commercial Banking Sector. British Journal of Marketing Studies, 2(2), 1-11.

Kariru, N. \& Aloo, C. (2014) customers' perceptions and expectations of service quality in hotels in western tourism circuit, Kenya. J. Res. Hosp.Tourism Cult, 2(1), 1-12.

Klemz, B. \& Boshoff, C. (2011) Environmental and emotional Influences on Willingness- toBuy in Small and Large Retailers. European Journal of Marketing, 35 (1-2), 70-91.

Lau, M., Cheung, R., Lam, A. \& Chu, Y. (2013). Measuring Service Quality in the Banking Industry: A Hong Kong Based Case Study of Contemporary Management Research Journal, 9(13), $263-282$. 
Messay, S. (2012).Bank Service Quality,Customer Satisfaction and Loyalty in Ethiopian Banking Sector. Journal of Business Administration and Management Sciences Research, $1,1-9$.

Odeny B.A (2016) the influence of service quality on performance of Barclays bank of Kenya

Ouyung, Y. (2010). A relationship between the financial consultant's service quality and Customer Satisfaction: Evidence from banking sector of Nigeria. International Journal of Business and Social Science, 4(2), 182-200.

Parasuraman, A., Zeithaml, V \& Berry, L. (1994).Reassessment of Expectations as a Comparison Standard in Measuring Service Quality: Implications for Further Research. The Journal of Marketing, 58, 111-124.

Ramzi, N. (2010). Effect of Service Quality on Customer Loyalty in Jordan Banks: The International Journal of Bank Marketing, 23(6/7), 508-526.

Saghier, N. \& Nathan, D.(2013) Service QualityDimension and Customer Satisfaction of Bank in Egypt. Proceedings of 20th International Business Research Conference pp 1-13.

Salim M. M. N. (2016) Factors affecting the quality of customer service in the banking industry in Kenya: a case of Ecobank Kenya, Nairobi region. A research project report submitted to United States international university - Africa

Seyed Abdullah Ebrahimzadeh Pahnecolai,(2015) Measuring Customer Satisfaction in the Retail Banking Sector of Iran Using RATER Model, Journal of Social Sciences and Humanity Studies

Timothy,A (2012) Electronic Banking Services and Customer Satisfaction in Nigerian Banking Industry. International Journal of Business and Management Tomorrow, 2(3), 1-8.

Toosi, N. \& Kohanali, R. (2011)The of study Airline Service Quality in the Qeshm free Zone by Fuzzy Logic. Journal of Mathematics and Computer Science, 2(1), 171-183.

Valluri, P. (2012). Role of alternate channels in banking and wealth management

Wachira, W. (2013) quality management practices and performance of supermarkets in Nairobi, MBA Project, University of Nairobi

Wafubwa M.A (2013) factors influencing performance of commercial banks in Kenya: a case of the Kenya Commercial Bank, Bungoma County.

This is an open-access article published and distributed under the terms and conditions of the $(\mathrm{cc}) \mathrm{EY}$ Creative Commons Attribution 4.0 International License of United States unless otherwise stated. Access, citation and distribution of this article is allowed with full recognition of the authors and the source.

Authors seeking to publish with an International Peer Reviewed Journal should consider www.ijcab.org by writing to the Editor at editor@ijcab.org. List of our Journals are Available at www.ijcab.org/journals

How to Cite

Chesaina, F., \& Gitonga, E. (2019). Service Delivery and Performance of Kenya Commercial Bank Limited: A Critical Review of Literature. International Journal of Current Aspects, 3(II), 71-82. https://doi.org/10.7176/ijcab.v3iII.7 